\title{
Effects of agro-chemicals practices in economic production of cabbage in valley districts of Manipur, India
}

\author{
Sonia Sagolsem*, N. Ram Singh, and Y. Chakrabarty Singh \\ (Manipur), India \\ *Corresponding author. E-mail: soniasaga2012@gmail.com \\ Received: August 18, 2015; Revised received: December 12, 2015; Accepted: March 20, 2016
}

Department of Agricultural Economics, College of Agriculture, Central Agricultural University, Imphal-795004

\begin{abstract}
Present investigation was conducted in Thoubal district and Imphal East district of Manipur, India to assemble the information about the economics of cabbage production, checking the practices done by farmers while using agro-chemicals and identifying the problems encountered by the producers in cabbage production. NPK was the most popular inorganic fertilizer amongst farmers. As such 59 farms applied fertilizer twice and 26 farms applied more than twice before harvesting. Different irrigation practices were encountered where use of pipes was more popular (53 farms) relative to the use of bucket irrigation (32 farms). Hoeing or hand fork were the most efficient tools for weed management (66 farms) followed by hand picking (21 farms). Majority of the farmers (79 farms) applied insecticides to control insect pest and fungicides as the major means of diseases management (78 farms). Overall the average cost of cultivation was worked out to be Rs. $18007.18 \mathrm{farm}^{-1}$ with the cost of large farms much higher than the small farms which is estimated as Rs. $26827.12 \mathrm{farm}^{-1}$ and Rs. $12126.35 \mathrm{farm}^{-1} \mathrm{re}^{-}$ spectively. The main problems faced by farmers were pest and diseases problems, insufficient irrigation, inadequate electricity for irrigation, infertility of soil, non-availability of fertilizers in time and suitable plant protection chemicals. The study concluded that cabbage farmer misused pesticides in terms of its types and quantity used in order to increase its production. In addition, consumers were exposed to high pesticide residue levels due to limited or no waiting period before cabbage heads were harvested.
\end{abstract}

Keywords: Agro-chemicals, Cabbage, Fungicides, Inorganic fertilizer, Insecticides

\section{INTRODUCTION}

Cabbage is a popular cultivar of the species Brassica oleracea Linne (Capitata group) of the family Brassicaceae (or Cruciferae) and is a leafy green vegetables. In India, It produces about 4.2 million tonnes of cabbage annually, which is about $9 \%$ of the world's total production of cabbage (FAO, 2002). Individually, cabbage accounts for about $5 \%$ of the total production of the country (Govt. of India, 2002). In India, problem of water shortage in summer, non availability of labour, availability of FYM, supply of chemical fertilizers and insecticides in time and non-availability of money for application of fertilizers and insecticides were also faced by the farmers (Bhople and Ambarkar, 1996). The application of either organic or synthetic fertilizers could increase pest populations on cabbage (Mochiah et al., 2011) The increased cost of plant protection chemicals was perceived as the most important factor followed by inadequate market facilities, poor storage and other post-harvest facilities, insufficient capital and high labour costs (Bonny, 1996). In most farm of India the net returns were highest on the largest size group of farms. The return from cabbage cultivation can be increased through increased use of fertilizer, manure, bullock labour, human labour and more area under this crop (Tripathi, 1999). The impact of land was positive and significant for small farms and negative and non significant for large farms (Bhalerao et at., 1983).

The improper use of pesticides is an issue of much concern. It has been estimated by the World Health Organization (WHO) that about 20,000 people die each year from pesticide poisoning and at least 3 million people suffer acute health effects (Barbara, 1993). Pesticide residue in food items have been a concern to consumer groups. Most pesticides especially, organochlorines are resistant to microbial degradation. They can, therefore, accumulate in human body fats and the environment posing problems to human health (Ejobi et al., 1996).

In Manipur, cabbage is grown as the popular vegetable. Cabbage covers the largest area and highest production compared with other vegetables. Cabbage occupied an area of 5720 ha and the production of 57624 metric tonne during 2010-2011 (Table 1). Cabbage production needs high cost of inputs such as pesticides, herbicides and fertilizers and attack by insect pests and diseases. The present study is to check the effects of agro-chemicals in the cost of cultivation of cabbage. It aims at checking the practices done by farmers for 
minimizing in particular, the unsafe use of agrochemicals in the production of cabbage in the study area.

\section{MATERIALS AND METHODS}

Questionnaires were designed to elicit information from cabbage farmers in Imphal East district and Thoubal district of Manipur. Proportionate number of farmers along with their land holding size of $\geq 0.25$ ha and $<0.25$ ha of each selected village was randomly selected to obtain primary data with regard to the economics of production of the crop. Thus the total sample size was about 100 cabbage growers from the five selected villages were put together. To meet the objectives of the study, both primary and secondary data were collected. Simple tabular analysis was done to accomplish the objectives.

The collected data were analyzed by using cost concept (Kahlon and Singh, 1992) in working out of cost and returns of cabbage production i.e. Cost A, Cost B, Cost $\mathrm{C}$ and Cost $\mathrm{D}$.

Cost $\mathbf{A}_{1}$ : It is calculated by summing the following costs; 1 . Value of seed 2 . Value of fertilizer and manure 3.Value of plant protection chemical 4. Hired human labour 5. Irrigation charges 6. Machinery charges 7.Depreciation on Farm Implements Used 8. Land Revenue 9. Interest on Working Capital 10.Charges for Land Preparation

Cost $A_{2}$ : Cost $A_{1}$ plus rent paid for leased-in land.

Cost B: Cost $A_{2}$ plus Imputed value of owned land (less land revenue paid thereupon).

Cost C: Cost B plus Imputed value of family labour.

Cost D: Cost $\mathrm{C}$ plus managerial cost (10\% of Cost $\mathrm{A}_{1}$ ) plus risk margin (10\% of Cost $\mathrm{A}_{1}$ )

\section{RESULTS AND DISCUSSION}

Socio-economic characteristics: Table 2 shows size of holding, farms workers, age group and educational levels of the farmers. The overall total farmers for both the category I and category II is 119.50 . Overall, the maximum numbers of farmers are in the age group of 46-55 $(28.00 \%)$ and $36-45$ years $(25.00 \%)$, followed by those in the age group of 25-35 years $(20.00 \%)$ and so on. Most of the cabbage farmers are in the younger to middle age group; hence any innovative change will be highly responsive. Also, the overall literacy rate is $58.93 \%$ which is highest in the high school level of education. The low level of education amongst farmers probably explains the indiscriminate use of pesticides due to ignorance on effect on humans and environment. Extremely low level of education has been reported to affect the level of technology adoption and skills acquisition amongst farmers (Oyekale and Idjesa, 2009).

Fertilizer and manure usage: The food production is characterized by no or very limited fertilizer application (Ennin and Dapaah, 2008). However, the situation is different in vegetable production where almost all the farmers used fertilizer to boost the production. Table 3 presents its usage by the farmers. Inorganic fertilizer was used by about 57 farms of the farmers while a meagre 10 farms used organic sources of fertilizer. NPK was the most popular inorganic fertilizer amongst farmers with urea application of 100 farms followed by SSP with 90 farms. Cabbage production was characterised by high used of inorganic fertilizer (NPK) which increased its productivity but have serious environmental degradation (Osei et al., 2013). Frequency of application of fertilizer was based on farmers' knowledge about the importance of the input to crop being cultivated and also on the financial strength of individuals. As such 59 farms apply fertilizer twice and 26 farms apply more than twice before harvesting. The majority of farmers who apply fertilizer more than twice stand a better chance of increasing their production levels compared with those who apply fertilizer once.

Irrigation requirement for cabbage production: $\mathrm{Cab}$ bage production requires lots of water as it is cole crop. Cabbage requires water management particularly in the dry season. Shortage of water leads to drought with obvious agricultural and societal impacts (Morrison et al., 2007). Inability to supply sufficient water during its growing period would result in total crop failure. Table 4 presents the type of irrigation system practiced by farmers. Different irrigation practices were encountered spanned from once daily to alternate days. Farmers em-

Table 1. Area, production and productivity of cabbage in all districts of Manipur during the year 2010-2011.

\begin{tabular}{lllll}
\hline S. N. & District & $\begin{array}{l}\text { Name of Crop } \\
\text { Cabbage Area (ha) }\end{array}$ & Production (MT) & Productivity (MT/ha) \\
\hline 1. & Imphal East(I/E) & 981 & 9908 & 10.09 \\
2. & Imphal West(I/W) & 869 & 8603 & 9.89 \\
3. & Bishnupur & 992 & 10218 & 10.30 \\
4. & Thoubal & 945 & 9828 & 10.40 \\
5. & Tamenglong & 217 & 2105 & 9.70 \\
6. & Senapati & 736 & 7213 & 9.80 \\
7. & Ukhrul & 495 & 4950 & 10.0 \\
8. & Chandel & 255 & 2499 & 9.80 \\
9. & Churchanpur & 230 & 2300 & 10.0 \\
& Total & 5720 & 57624 & 10.07 \\
\hline
\end{tabular}

Source: Directorate of Horticulture and Soil Conservation of Manipur 
Table 2. Socio-economic characteristics of sample farmers.

\begin{tabular}{|c|c|c|c|c|}
\hline S. N. & Particulars & $\begin{array}{l}\text { Farm category } \\
\text { Category I }(\geq 0.25 \text { ha })\end{array}$ & Category II $(<0.25$ ha $)$ & Overall \\
\hline & Size of farms and farms workers & & & \\
\hline 1. & No. of farms & 40 & 60 & 100 \\
\hline 2. & Total operational holding (ha) & 12.30 & 6.50 & 18.80 \\
\hline 3. & Average size of farm (ha) & 0.31 & 0.11 & 0.19 \\
\hline \multirow[t]{3}{*}{4.} & Farm workers & & & \\
\hline & Male & $77(75.49)$ & $98(71.53)$ & $87.5(73.22)$ \\
\hline & Female (man equivalent) & $25(24.51)$ & $39(28.47)$ & $32(26.78)$ \\
\hline \multirow[t]{2}{*}{5.} & Total worker & $102(100)$ & $137(100)$ & $119.5(100)$ \\
\hline & Age group of farmers & & & \\
\hline 1. & $25-35$ & $8(20.00)$ & $12(20.0)$ & $20(20.00)$ \\
\hline 2. & $36-45$ & $12(30.00)$ & $13(21.67)$ & $25(25.00)$ \\
\hline 3. & $46-55$ & $8(20.00)$ & $20(33.33)$ & $28(28.00)$ \\
\hline 4. & $56-65$ & $7(17.50)$ & $9(15.00)$ & $16(16.00)$ \\
\hline 5. & Above 65 & $5(12.50)$ & $6(10.0)$ & $11(11.00)$ \\
\hline \multirow[t]{2}{*}{6.} & Total & $40(100)$ & $60(100)$ & $100(100)$ \\
\hline & Educational status & & & \\
\hline 1. & Illiterate & $97(39.11)$ & $133(42.63)$ & $230(41.07)$ \\
\hline 2. & High school & $82(33.07)$ & $107(34.39)$ & $189(33.75)$ \\
\hline 3. & Secondary & $48(19.36)$ & $43(13.78)$ & $91(16.25)$ \\
\hline 4. & Graduate \& above & $21(8.47)$ & $29(9.30)$ & $50(8.93)$ \\
\hline 5. & Total & $248(100)$ & $312(100)$ & $560(100)$ \\
\hline 6. & Literacy rate $(\%)$ & 60.89 & 57.37 & 58.93 \\
\hline
\end{tabular}

Source: Field survey, 2012

Table 3. Fertilizer and manure usage.

\begin{tabular}{llll}
\hline & & Farm category & \\
\cline { 2 - 4 } Particulars & Category I ( 40 farms ) & Category II ( 60 farms ) & Overall ( 100 farms ) \\
\hline Type of fertilizer used & 6 & 4 & 10 \\
Organic & 22 & 35 & 57 \\
Inorganic & 12 & 21 & 33 \\
Both & & & \\
Type of inorganic fertilizer & 40 & 60 & 100 \\
Urea & 22 & 41 & 63 \\
Muriate of Potash & 38 & 52 & 90 \\
SSP & & & \\
Frequency of application & 11 & 14 & 25 \\
Once & 27 & 32 & 59 \\
Twice & 2 & 24 & 26 \\
More than Twice & & & \\
\hline
\end{tabular}

Source: Field survey, 2012

Table 4. Irrigation system practices by farmers.

\begin{tabular}{llll}
\hline & & Category & \\
\cline { 2 - 4 } Particulars & Category I ( 40 farms ) & Category II ( 60 farms ) & Overall ( 100 farms ) \\
\hline Type of irrigation system & 9 & 6 & 15 \\
Watering can & 15 & 17 & 32 \\
Bucket & 16 & 37 & 53 \\
Pipe & & & 64 \\
Irrigation frequency & 21 & 43 & 28 \\
Once daily & 11 & 17 & 18 \\
Twice daily & 8 & 10 & 34 \\
Alternate days & & & 49 \\
Source of irrigation water & 16 & 18 & 17 \\
Pond & 17 & 32 & \\
Stream & 7 & 10 & \\
Other & & & \\
\hline
\end{tabular}

Source: Field survey, 2012 
Table 5. Management practices on cabbage farms.

\begin{tabular}{|c|c|c|c|}
\hline \multirow{2}{*}{ Particulars } & \multicolumn{3}{|c|}{ Farm Category } \\
\hline & Category I ( 40 farms ) & Category II ( 60 farms ) & Overall ( 100 farms ) \\
\hline \multicolumn{4}{|l|}{ Weed management } \\
\hline Hand picking & 11 & 10 & 21 \\
\hline Hoeing or use of hand fork & 40 & 26 & 66 \\
\hline Application of herbicides & 9 & 4 & 13 \\
\hline \multicolumn{4}{|l|}{ Insect pest mangement } \\
\hline Hand picking and destruction & 2 & 6 & 8 \\
\hline Rotation of crops & 2 & 2 & 4 \\
\hline Intercropping & 4 & 5 & 9 \\
\hline Application of pesticides & 32 & 47 & 79 \\
\hline \multicolumn{4}{|l|}{ Diseases management } \\
\hline Rouging of infected plants & 6 & 10 & 16 \\
\hline Rotation of crops & 5 & 1 & 6 \\
\hline Application of fungicides & 29 & 49 & 78 \\
\hline
\end{tabular}

Source: Field survey, 2012

Table 6. Cost of cultivation of cabbage for different categories of farms.

\begin{tabular}{|c|c|c|c|c|}
\hline \multirow{2}{*}{\multicolumn{2}{|c|}{ Particulars }} & \multirow{2}{*}{\multicolumn{3}{|c|}{ Farm Category }} \\
\hline & & & & \\
\hline A. & iable cost & $\begin{array}{l}\text { Category I } \\
\geq 0.25 \text { ha ( } 40 \text { farms ) } \\
\end{array}$ & $\begin{array}{l}\text { Category II } \\
<0.25 \text { ha ( } 60 \text { farms ) } \\
\end{array}$ & $\begin{array}{l}\text { Overall } \\
(100 \text { farms })\end{array}$ \\
\hline 1. & Seed & $658.50(2.46)$ & 206.67(1.71) & $387.40(2.15)$ \\
\hline 2. & Fertilizer \& Manure & $1886.25(7.03)$ & $788.33(6.50)$ & $1227.50(6.82)$ \\
\hline 3. & PPC & $436.75(1.63)$ & 195.66(1.61) & 292.10(1.62) \\
\hline 4. & Hired Human labour & $3216.20(11.99)$ & $1247.30(10.29)$ & 2035.28(11.30) \\
\hline 5. & Irrigation & 2966.25(11.06) & $1457.66(12.02)$ & 2061.10(11.45) \\
\hline 6. & Hire Machine & 2987.50(11.14) & $824.66(6.80)$ & $1689.80(9.39)$ \\
\hline 7. & Interest on working capital & $303.79(1.13)$ & 118.0190.97) & $192.32(1.0)$ \\
\hline 8. & $\begin{array}{l}\text { Rental value for lease in } \\
\text { land }\end{array}$ & $0(0)$ & $0(0)$ & $0(0)$ \\
\hline \multicolumn{5}{|c|}{ B. Fixed Cost } \\
\hline 1. & Family labour & $6433.2(23.98)$ & $4326.00(35.68)$ & $5168.88(28.71)$ \\
\hline 2. & Depreciation & 245.95(0.98) & $147.00(1.21)$ & $186.58(1.04)$ \\
\hline 3. & Land revenue & $43.75(0.16)$ & $15.00(0.13)$ & $26.50(0.15)$ \\
\hline 4. & Interest on fixed capital & $215.58(0.80)$ & $78.00(0.64)$ & $133.32(0.74)$ \\
\hline & $\begin{array}{l}\text { Imputed rental value of owned } \\
\text { Land }\end{array}$ & $5100.00(19.01)$ & $1800.00(14.84)$ & $3120.00(17.33)$ \\
\hline 6. & Managerial cost & $1274.49(4.75)$ & $500.03(4.12)$ & $809.86(4.50)$ \\
\hline 7. & Risk margins & $1274.49(4.75)$ & $500.03(4.12)$ & $809.86(4.50)$ \\
\hline & Cost $A_{1}$ & 12744.94 & 5000.29 & 8098.58 \\
\hline & Cost $A_{2}$ & 12744.94 & 5000.29 & 8098.58 \\
\hline & Cost B & 17844.94 & 6800.29 & 11218.58 \\
\hline & Cost $\mathrm{C}$ & 24278.14 & 11126.29 & 16387.46 \\
\hline & Cost D & 26827.12 & 12126.35 & 18007.18 \\
\hline
\end{tabular}

Note: Figures in parentheses denote the percentage to the cost D

ployed inefficient irrigation system; the use of watering cans in cabbage production. The use of pipes to supply the water needs of cabbage crop was more popular (53 farms) relative to the use of bucket irrigation (32 farms). The major source of irrigation water was stream. However, lack of adequate finances has compared majority of the farmers to use pipes and watering cans resulting in lower production levels.

Common management for cabbage production: Table 5 show three methods of weed management were employed; hand picking, use of garden tools (as hoes, hand fork) and application of herbicides. Hoeing or hand fork were the most efficient tools for weed management (66 farms) followed by hand picking ( 21 farms). Farmers took weed management seriously which was insurance for higher yields. Noxious weeds infestation has been reported to reduce yield of crops (Awodoyin, 2007).

Cabbage plants attract a number of insect pests at different stages of the plant growth due to their nutritive and luxuriant nature. Failure to manage insect pests could result in total crop failure. Pesticide application has become indispensable to control insect pest for cabbage production and farmers misused the pesticides which 
affect the quality and safety of cabbage heads produced for consumption (Amoako et al., 2012 and Badii et al., 2013). Majority of the farmers (79 farms) applied insecticides to control insect pest. Farmers identified many diseases that affect its productivity. Application of fungicides was the major means of management (78 farms) followed by rouging of infected plants (16 farms).

Cost of cultivation: Table 6 show the overall average cost of cultivation was worked out to be Rs. Rs. 18007.18 farm $^{-1}$. The total cost of cultivation on large farms (category I) was much higher than the small farms (category II), which is estimated as Rs. 26827.12 and Rs. 12126.35 respectively for these two categories of farms. Irrigation charges and fertilizer and manure charges were important inputs used by the cabbage farmers. Plant protection chemicals is another key input in vegetable production was also found to be used.

Constraints faced by farmers: The main problems faced by farmers are pest and diseases problems, insufficient irrigation, inadequate electricity for irrigation, infertility of soil, non-availability of fertilizers in time and suitable plant protection chemicals, poor market facilities, lack of technical assistance, poor quality of seed and high cost of seed.

\section{Conclusion}

From the above finding concluded that the total cost of cultivation for an overall is Rs. 18007.18 per farm in which large farms (category I) with the cost of large farms much higher than the small farms which is estimated as Rs. 26827.12 farm $^{-1}$ and Rs. 12126.35 farm $^{-1}$ respectively. It was found that they spend lots of expenditure on irrigations, fertilizer and manure and also on plant protection chemical. To ensure healthy and high productivity, cabbage farmers abuse the use of synthetic products like herbicides, pesticides, fungicides and fertilizers which have serious environmental implications. The excess and improper application of chemicals products completely outweigh any merits the practice may import. The information gathered from this baseline study would form the basis for the formulation and implementation of an integrated pest management (IPM) strategy to enhance safe and environmentally sustainable production of cabbages. The study concluded that cabbage farmer misused pesticides used in terms of its types and quantity used in order to increase the cabbage production. In addition, consumers were exposed to high pesticide residue levels due to limited or no waiting period before cabbage heads were harvested. To mitigate the identified problems, stakeholders such as Ministry of Food and Agriculture and Associations of Agrochemical Dealers must form a common platform to combat the importation and smuggling of banned pesticides into the country and intensify the education, training and information dissemination activities on pesticides and their residual effects in all the farming communities in the country. This would reduce environmental degradation and ensure maximum protection for humans, domestic animals and wild life.

\section{REFERENCES}

Amoako, P.K., Kumah, P. and Appiah, F. (2012). Pesticides usage in Cabbage (Brassica oleracea) Cultivation in the Ejisu-Juaben Municipality of the Ashanti Region of Ghana. International Journal of Research in Chemistry and Environment, 2 (3): 26-31

Awodoyin, R.O., Ogbeide, F.I. and Olufemi, O. (2007). Effect of three mulch types on the growth and yield of tomato and weed suppression in Ibadan, rainforest-savanna zone of Nigeria. Trop. Agric. Res. Ext. 10: 53-60.

Badii, K.B., Adarkwah, C. and Nboyine, J.A. (2013). Insecticide Use in Cabbage Pest Management in Tamale Metropolis of Ghana. Greener Journal of Agricultural Sciences. 3(5): 403-411

Barbara, S. (1993). The Pesticides Hazards. Zeb book Ltd in Association with Pesticide Trust. London and USA, pp 3-5.

Bhalerao, M.M., Ansari, S.I. and Venkateswar, M. (1983). Efficiency of resource use in vegetable production. The Andhra Journal. 30 (2): $112-115$.

Bhople, R.S. and Ambarkar, K.S. (1996). Production, storage and marketing constraints of vegetable growers. P.K.E. Research Journal 20(1): 31-33.

Bonny, P.B. (1996). Constraints in commercial production of vegetables. Journal of Tropical Agriculture, 34(2): 159-160.

Ejobi, F, Kanja, LW., Kyule, M.N., Muller, P., Kruger, J. and Latigo, A.A.R. (1996) . Organochlorine pesticide residues in mother's milk in Uganda. Bull Environ. Contam. Toxicol. 56: 873-880.

Ennin, S.A. and Dapaah, H.K. (2008). Legumes in sustainable maize and cassava cropping systems in Ghana. Agric. Food Sci. J. Ghana. 7: 519-540.

FAO (2002). FAO Statistical Database from http://apps.fao.org.

Govt. of India (2002). Economic Survey 2001-2002, Ministry of Finance, New Delhi. pp 191-192.

Directorate of Horticulture and Soil conservation (2011). Area and Production of Cabbage in Manipur, 2010-2011, Govt. of Manipur from http://www.nhb.nic.in

Kahlon, A.S. and Karam Singh (1992). Economics of Farm Management in India, Theory and Practice. Allied publisher Ltd. pp. 88-99.

Mochiah, M,B., Baido, P.K. and Owusu-Akyaw, M. (2011). Influence of different nutrient applications on insect populations and damage to cabbage. Journal of Applied Biosciences. $38: 2564-2572$.

Morrison, J.I.L., Baker, N.R, Mullineaux, P.M. and Davies,W.J. (2007). Improving water use in crop production. DOI:10.1098/rstb.2007.2175.

Osei M.K., Osei, K., Braimah, H., Mochiah,. M.B, Berchie, J.N., Bolfrey-Arku ,G., Lamptey, J.N.L. (2013). Practices and constraints to cabbage production in urban and periurban Ghana: Focus on Brong Ahafo and Ashanti Regions. Basic Research J. of Agril Science and Review. 2 (1) : : 05-14

Oyekale, A.S. and Idjesa, E. (2009). Adoption of improved maize seed and production efficiency in River State, Nigeria. Acad. J. Plant Sci. 2:44- 50.

Tripathi, R.S. (1999). Economics of cabbage production in high-hills of Uttar Pradesh. Indian Journal of Horticulture, 56(4) : 343-347 